\title{
Potassium fertilization in the quality improvement and centesimal composition of pitaya
}

\author{
Josimara Mendes Rabelo, Maria do Céu Monteiro da Cruz, Cíntia Gonçalves Sena, \\ Lílian de Araújo Pantoja, Alexandre Soares dos Santos, Letícia Alves Carvalho Reis, \\ Amanda Gonçalves Guimarães*
}

University of Jequitinhonha and Mucuri Valleys, Campus JK, BR-367, 5000, Diamantina, MG, 39100-000, Brazil

\section{A B S T R A C T}

\begin{abstract}
Pitaya stands out in the market for presenting exotic appearance species, high water content, vitamins and minerals, low calories, and bioactive compounds that makes it attractive for consumption However, the composition of this fruit may change according from the place of cultivation, orchard management and harvesting season. Regarding orchards management, variations have been observed in the fact that the pitaya species are considered rustic, able of tolerating adverse conditions of low availability of water and nutrients, and mainly because lack information on fertilization. Thus, the research was carried out to evaluated the potassium fertilization in the quality and in the centesimal composition in pitayas of the species Hylocereus undatus and Hylocereus polyrhizus. The evaluations were carried out during two harvests, in pitayas harvested mature from plants that received different fertilizations. The fruits of the pitaya species reach larger sizes and better flavor with the potassium fertilization. The fruits centesimal composition is altered with the management of the fertilization of the orchards. The fruits produced by plants with higher availability of potassium oxide $\left(\mathrm{K}_{2} \mathrm{O}\right)$ present higher contents of dry matter, fiber, ashes, carbohydrates and energetic value and lower moisture content, allowing conservation for longer if stored properly. The increase of these constituents in the fruit pulp is related to the function of potassium (K) in the enzyme's activation, which are fundamental in the metabolic processes and the transport of photoassimilates, evidencing their role in improving fruit quality characteristics. Orchards that are fertilized with potassium produce fruits with better composition and final quality, increasing the acceptance by consumers, size classification and market prices.
\end{abstract}

Keywords: Chemical composition; Nutritional composition; Physicochemical properties

\section{INTRODUCTION}

Pitaya is a new one in the world, this because until 1994, only scarce research existed on these fruits, however the worldwide interest in this novel fruit crop is evident, as numbers of pitaya-related publications have grown rapidly, especially during the past decade (Mizrahi, 2014). These researches attracted the attention of consumers, due to the potential beneficial to health and of producers, by their economic value in the market.

The studies related to the characterization evidenced that the pitayas are rich in vitamins, minerals, linoleic acid and oleic acid and antioxidant potential (Nurul and Asmah, 2014; Cordeiro et al., 2015; Jerônimo et al., 2015). They are similar to other fruits, most of its composition is water, the moisture content in the pulp varies between $85 \%$ and 89.9\% (Sato et al., 2014; Nurul; Asmah, 2014; Jerônimo et al.; 2015). Regarding the levels of proteins, fruits of the species $H$. undatus and $H$. polyrbizus purchased at a CEASA unit in Brazil, the contents evaluated ranged from $0.87 \mathrm{~g}$

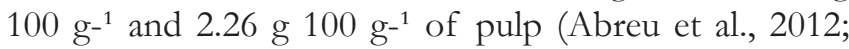
Jerônimo et al., 2015).

Pitayas have low levels of lipids. Results published in fruits produced in Brazil showed levels ranging from $0.3 \mathrm{~g}-^{1}$ $100 \mathrm{~g}^{-1}$ to $0.47 \mathrm{~g} 100 \mathrm{~g}^{-1}$, for H. undatus and H. polyrbizus (Abreu et al., 2012, Santos et al., 2016) and rich in fibers with values ranging from $2.14 \mathrm{mg} 100 \mathrm{~g}^{1}{ }^{1}$, in pitayas produced by $H$. undatus and from $3.26 \mathrm{mg} 100 \mathrm{~g}^{1}$ to $11.35 \mathrm{~g}$ $100 \mathrm{~g}-^{1}$, in fruits of the species H. polyrbizus (Cordeiro et al., 2015).

As for ash contents, results published in the characterization carried out in pitayas produced in Brazil report values from $0.33 \mathrm{~g} 100 \mathrm{~g}-^{-1}$ to $0.75 \mathrm{~g} 100 \mathrm{~g}-^{-1}$ in the fruit pulp of H. undatus

\footnotetext{
*Corresponding author:

Amanda Gonçalves Guimarães, University of Jequitinhonha and Mucuri Valleys, Campus JK, BR-367, 5000, Diamantina, MG, 39100-000,

Brazil. E-mail: amandagguimaraes@yahoo.com.br
}

Received: 21 March 2020; $\quad$ Accepted: 12 August 2020 
and H. polyrbizus (Abreu et al., 2012 Jerônimo et al., 2015). Among the constituents in the composition of pitayas, the levels of carbohydrates are also variable. H. polyrbizus fruits harvested in Malaysia showed levels of $12.9 \mathrm{~g} 100 \mathrm{~g}-^{1}$ and $8.4 \mathrm{~g} 100 \mathrm{~g}-^{-1}$, for those harvested in Australia. In Brazil, in fruits of the species $H$. undatus, a content of $10.79{\mathrm{~g} 100 \mathrm{~g}^{-1}}^{-1}$ has been reported (Jerônimo et al., 2015).

It is possible to note that the composition of the pitayas can vary between species, soil and climatic conditions of the place cultivation and with the conditions of orchards management. Further, the conditions during storage may also influence the composition and final quality of these fruit (Freitas et al., 2013, and Duarte et al., 2017).

Research relating the composition and quality of pitayas with orchard management are still scarce. Regarding fertilization, the studies carried out by Duarte et al. (2017) with management of organic fertilization and Fernandes et al. (2018) with the management of potassium fertilization showed that fertilization is one of the factors that directly interferes in the quality of these fruits, but specifically in the centesimal composition no information has been disclosed yet.

Quality is important for commercialization because it involves characteristics related to fruit size and flavor, such as the sugars concentration and the acidity in its pulp, variables that characterize the smooth-flavored pitayas, which may hinder its acceptance in the consumer market.

To improve the quality and composition of the pitayas produced, plant nutrition is determinant, considering the nutrients' participation in the flavor, color, aroma, form, size, appearance, resistance to pests and diseases, and preservation during post-harvest storage of fruit (Aular and Natale, 2013), because in addition to the nutritional value of fruit, consumers are demanding more in relation to quality.

Potassium $(\mathrm{K})$ is one of the essential mineral nutrients to plants, which participates in biochemical and physiological functions as the activation enzymes, which are fundamental in the metabolic processes, for the proteins and sugars production; and in the transport of sugars produced by photosynthesis to the fruits (Senapati and Santra, 2009; IPI, 2013).

In this context, the research was conducted with the objective of evaluated the effect of potassic fertilization on the quality and in the centesimal composition of pitayas of the species Hylocereus undatus and Hylocereus polyrhizus.

\section{MATERIALS AND METHODS}

The evaluated pitayas were harvested in an orchard located at $18^{\circ} 04^{\prime} 15^{\prime \prime}$ latitude and $43^{\circ} 28^{\prime} 15^{\prime \prime} \mathrm{W}$ longitude at an altitude of 726 meters. The region has an Aw climate type, classified as high-altitude tropical, with a mean temperature of $21.5^{\circ} \mathrm{C}$ and precipitation of $1,246 \mathrm{~mm}$ per year.

The soil of the orchard is the Yellow-Dystrophic Latosol, with following characteristics: $\mathrm{pH}=4.1$; phosphor $(\mathrm{P})=52.3$ $\mathrm{mg} \mathrm{dm}{ }^{-3} ; \operatorname{potassium}(\mathrm{K})=40.7 \mathrm{mg} \mathrm{dm}^{-3} ; \operatorname{calcium}(\mathrm{Ca})=1.2$ cmolc $\mathrm{dm}^{-3}$; magnesium $(\mathrm{Mg})=0.7 \mathrm{cmolc} \mathrm{dm}^{-3}$; aluminum $(\mathrm{Al})=1.13 \mathrm{cmolc} \mathrm{dm}^{-3}$; organic matter $=0.4 \mathrm{dag} \mathrm{kg}^{-1}$; base saturation $=25 \%$ and cation exchange capacity at pH $7=9.4 \mathrm{cmolc} \mathrm{dm}^{-3}$.

\section{Experimental design and complementary fertilization} For the application of the doses of potassium oxide $\left(\mathrm{K}_{2} \mathrm{O}\right)$ tested the $2 \times 4$ factorial scheme was used, the factors are related to two pitaya species, Hylocereus undatus (Haw.) and Hylocereus polyrbizus (Web.) Britton \& Rose and four doses of $\mathrm{K}_{2} \mathrm{O}, 0 ; 50 ; 100$ and $200 \mathrm{~g}$ per plant, distributed in randomized blocks, composed of four blocks and three plants per plot.

Complementary fertilization of the orchard was carried out with nitrogen $(\mathrm{N}), \mathrm{P}, \mathrm{Ca}, \mathrm{Mg}$ and bovine manure. Before planting, the soil was prepared with limestone that provides $\mathrm{Ca}$ and $\mathrm{Mg}$ and raise the bases saturation to $60 \%$ and fertilized with $50 \mathrm{~g}$ of $\mathrm{P}$ and 10 liters of bovine manure. After planting, $100 \mathrm{~g}$ of $\mathrm{N}$ were applied per plant, divided into three applications, in all production cycles evaluated.

\section{Analyses}

The fruits were harvested when the peel color was completely red, during the summer in the growing region, between the months of December and March. The analyzes were in two productive cycles, in the third and fourth harvest after the orchard implantation. After harvest as pitayas were carried out at the Laboratory of fruit analysis for sample preparation and analysis. In Laboratory the fruits were washed in water and allowed to air-dry.

To assess the fruits quality were analyzed for longitudinal diameter, transverse diameter, mass, soluble solids content ( ${ }^{\circ}$ Brix), titratable acidity ( $\%$ of malic acid equivalents) soluble solids/titratable acidity ratio and the concentration of total sugars.

Soluble solids contents were quantified using a digital refractometer. For titratable acidity in $0.1 \mathrm{M} \mathrm{NaOH}$, according to methodology of the IAL (2008). Determination of the total soluble sugars adapted by McCready (1950). From the results of the soluble solids concentration and 
acidity titratable, the soluble solids and titratable acidity e ratio was calculated.

To evaluate the centesimal composition, pulp samples of 40 fruits harvested in the plants of each fertilization, at each harvest season, were withdrawn. The samples were placed in Petri dishes to dry in a forced circulation oven at $65^{\circ} \mathrm{C}$ until reaching a constant mass.

Moisture content; ash; crude fiber, lipids; and protein were determined according to standard IAL (2008) in mature fruits (Fig. 1). All samples were analyzed in triplicate and were expressed as mg $100^{-1} \mathrm{~g}$ dry matter. Carbohydrates concentration were determined by the difference of water, protein, lipid and ashes contents, according the methodology proposed by Brazil (2003).

\section{Statistical analyses}

The data were submitted to analysis of variance and the variables with significant differences between the $\mathrm{K}_{2} \mathrm{O}$ doses tested were submitted to regression analysis, considering a $p<0.05$.

The multivariate analysis was performed by means of the canonical variable (HAIR et al., 2009), for the joint analysis of the doses of $\mathrm{K}_{2} \mathrm{O}$ in the two pitaya species and in the two harvests evaluated.

From the equation obtained, the dose of $\mathrm{K}_{2} \mathrm{O}$ was estimated for the highest value of the canonical variable that was used in the regression equations of the quality and the centesimal composition variables of the pitayas.

\section{RESULTS}

The quadratic equation was the one that best explained the variation of the canonical variable as a function of the $\mathrm{K}_{2} \mathrm{O}$ doses, for the quality and the centesimal composition variables of the pitayas, in the two productive cycles (Fig. 2).

According to the adjusted model, the dose of $\mathrm{K}_{2} \mathrm{O}$ that provides the fruits production of better quality and centesimal composition is $144 \mathrm{~g}$ of $\mathrm{K}_{2} \mathrm{O}$ per plant. Potassium fertilization increases fruit size, soluble solids, fiber, ash, carbohydrate and dry matter (Table 1).

\section{Fruit quality}

The mass and the diameters in the pitayas of the H. undatus species increased with the greater availability of potassium

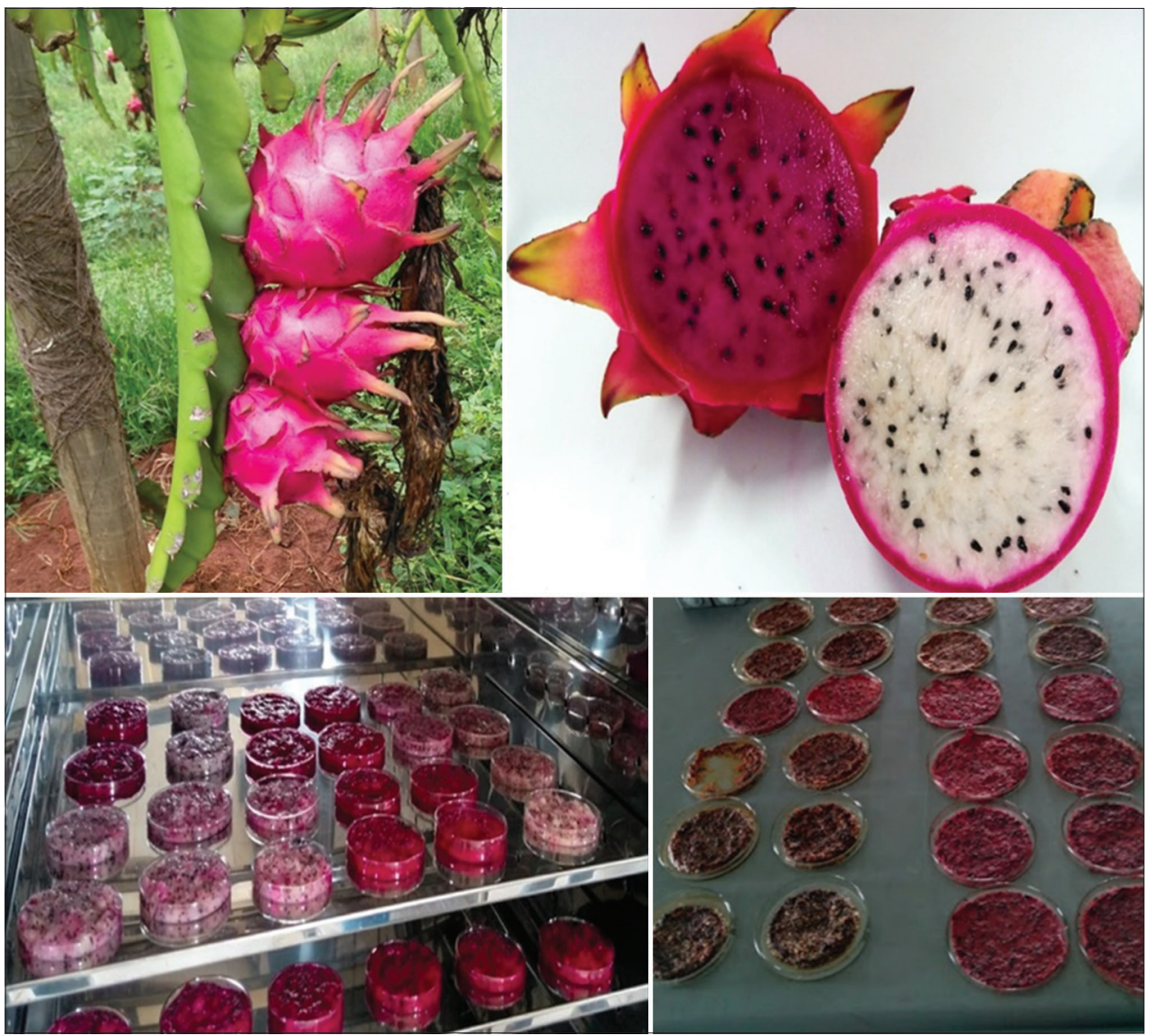

Fig 1. Preparation of samples for analysis of lipids, ashes, carbohydrates, protein and sugars, of white pitaya $H$. undatus and red pitaya H. polyrhizus. 


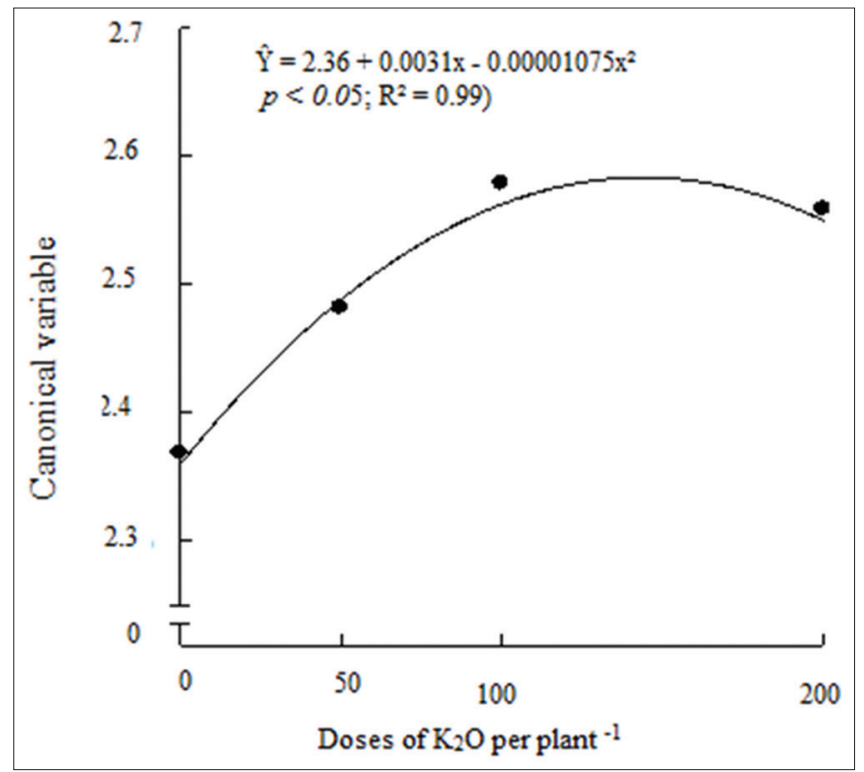

Fig 2. Score of the canonical variable of the multivariate analysis as a function of the doses of $\mathrm{K}_{2} \mathrm{O}$ for the variables of quality and centesimal composition of the pitayas, in the third and fourth productive cycles.

Table 1: Mean values of quality and centesimal composition variables of pitayas, resulting from analysis of variance and canonical variable (CV), as a function of the doses of $\mathrm{K}_{2} \mathrm{O}$

\begin{tabular}{lcccc}
\hline Variables & \multicolumn{4}{c}{ Doses of $\mathbf{K}_{\mathbf{2}} \mathbf{O}$ (g plant ${ }^{-1}$ ) } \\
\cline { 2 - 5 } & $\mathbf{0}$ & $\mathbf{5 0}$ & $\mathbf{1 0 0}$ & $\mathbf{2 0 0}$ \\
\hline Mass (g) & 146.8 & 178.05 & 190.7 & 196.4 \\
Transverse diameter (mm) & 59.5 & 70.5 & 74.5 & 70.7 \\
Longitudinal diameter (mm) & 61.4 & 70.4 & 74.1 & 72.5 \\
Soluble solids ('Brix) & 17.1 & 19.1 & 19.5 & 18.6 \\
Titratable acidity (TA) (\%) & 0.3 & 0.28 & 0.27 & 0.28 \\
Total sugars (\%) & 7.2 & 7.5 & 8.6 & 8.7 \\
SS/TA Ratio & 72.1 & 80.6 & 86.6 & 80.7 \\
Proteins (\%) & 1.0 & 0.99 & 0.87 & 0.99 \\
Lipids (\%) & 1.54 & 1.13 & 1.20 & 1.33 \\
Fibers (\%) & 2.39 & 2.37 & 3.22 & 3.09 \\
Ashes (\%) & 0.39 & 0.50 & 0.56 & 0.63 \\
Moisture (\%) & 86.9 & 85.2 & 84.4 & 83.7 \\
Carbohydrates (\%) & 10.3 & 12.4 & 12.9 & 13.4 \\
Dry matter (\%) & 13.2 & 14.9 & 15.5 & 16.0 \\
Canonical variable (CV) ${ }^{1 /}$ & 2.37 & 2.48 & 2.58 & 2.56 \\
\hline
\end{tabular}

$1 / \mathrm{CV}=0.01083612$ * protein -0.02334588 * lipids +0.06523551 * fibers +0.73489504 * ashes +0.01667250 * moisture +0.00761084 * carbohydrates $-0.01376635^{*}$ sugars $-0.00032907^{*}$ dough total mass $+0.00593143^{*}$ transverse diameter -0.00224888 * longitudinal diameter $+0.01588613^{*}$ Soluble solids +0.21979416 * Acidity +0.00199253 * SS/TA ratio -0.01062828 * dry mass with auto value $=83 \%$

for the plants (Table 2). Maximum values for the fruit quality variables were calculated from the $144 \mathrm{~g}$ dose of $\mathrm{K}_{2} \mathrm{O}$ per plant (Fig. 1).

The results observed in relation to the size of the fruit show increases in mass and diameters in the pitayas of the two species, in the two harvests evaluated (Tables 2).

The mass is one of the important variables to classify the fruits for commercialization, the size observed in the fruits of the plants that did not receive potassium fertilization masses changed from 136 to $165 \mathrm{~g}$, while the fruits produced by the plants fertilized with $144 \mathrm{~g}$ of $\mathrm{K}_{2} \mathrm{O}$ presented mass of 191 to $203 \mathrm{~g}$, representing increments of $17 \%$ and $36 \%$ (Table 2).

In the $H$. polyrbizus species, fertilization with $144 \mathrm{~g}$ of $\mathrm{K}_{2} \mathrm{O}$ per plant provided the production of fruits with a transverse diameter of $78.5 \mathrm{~mm}$ and longitudinal diameter between $78.5 \mathrm{~mm}$ to $81.72 \mathrm{~mm}$, and mass of $195 \mathrm{~g}$ to $200 \mathrm{~g}$, $25 \%$ higher than fruit of plants that were not fertilized with K (Table 2).

In relation to the chemical characteristics evaluated, the fruits of $H$. undatus fertilized with $\mathrm{K}_{2} \mathrm{O}$ showed differences in relation to soluble solids and total sugars and titratable acidity (Table 2), soluble solids contents at $17.7^{\circ}$ Brix and total sugars $6.4 \%$ to $8.9 \%$ with the dose of $144 \mathrm{~g}$ of $\mathrm{K}_{2} \mathrm{O}$ per plant, whereas in the fruits of the non-fertilized plants the values of soluble solids observed ranged from $16.3^{\circ}$ Brix to $16.7^{\circ}$ Brix and $5.4 \%$ to $7.4 \%$ of sugars, in the two cycles evaluated and acidity reduction from $0.23 \%$ to $0.18 \%$. In the H. polyrbizus fruits fertilized with the 144 $\mathrm{g}$ dose of $\mathrm{K}_{2} \mathrm{O}$, soluble solids contents reached $22.1^{\circ}$ Brix to $20.2^{\circ}$ Brix, and $7.4 \%$ and $11.6 \%$ sugars, and the acidity ranged from $0.24 \%$ to $0.17 \%$ (Table 2 ), in the third and fourth cycle, respectively.

The titratable acidity ranged from $0.51 \%$ to $0.19 \%$ in the fruits of $H$. undatus and from $0.24 \%$ to $0.17 \%$ in the fruits of H.polyrbizus in the two harvests evaluated. The SS / TA ratio varied from 34.4 and 81.7 , in the fruits of $H$. undatus and from 88.3 to 123 , in the fruits of $H$. polyrbizus (Table 2).

\section{Centesimal composition}

For the protein and lipid contents, no differences were observed in the fruits, in the harvests evaluated (Table 3).

Fibers contents increased in the two harvests evaluated, from $2.3 \%$ to $3.3 \%$ and $3.01 \%$ to $3.6 \%$, in the pitayas of the $H$. undatus species and from $1.5 \%$ to $2.2 \%$ and $2.2 \%$ to $2.8 \%$, in the pitayas of the $H$. polyrbizus (Table 3 ).

The ash contents increased in the pitayas with potassium fertilization, varying from $0.5 \%$ to $0.68 \%$ and $0.3 \%$, to $0.55 \%$, in the $H$. undatus species, in the productive cycles, respectively. In the pitayas of the $H$. polyrbizus the contents varied from $0.49 \%$ to $0.60 \%$ and $0.33 \% 0.48 \%$ (Table 3 ), comparing fruit harvested in plants that did not receive potassium fertilization and fruits of plants fertilized with the dose of $144 \mathrm{~g}$ of $\mathrm{K}_{2} \mathrm{O}$.

Carbohydrates increased with availability of $\mathrm{K}_{2} \mathrm{O}$ for plants. In the fruits of the $H$. undatus, concentrations increased 
Table 2: Equation of Regression and determination coefficients $\left(R^{2}\right)$ for mean total fruit mass, transverse diameter, longitudinal diameter, soluble solids content, titratable acidity (TA), total sugars and the SS/TA ratio, in function of the $\mathrm{K}_{2} \mathrm{O}$ doses in pitayas of the species Hylocereus undatus and Hylocereus polyrhizus in the second and third productive cycles

\begin{tabular}{|c|c|c|c|c|c|c|}
\hline \multirow[t]{3}{*}{ Variables } & Equation & $\mathbf{R}^{2}$ & $\begin{array}{l}\text { Maximum } \\
\text { value }\end{array}$ & Equation & $\mathbf{R}^{2}$ & $\begin{array}{l}\text { Maximum } \\
\text { value }\end{array}$ \\
\hline & \multicolumn{3}{|l|}{ H. undatus } & \multicolumn{3}{|l|}{ H. polyrhizus } \\
\hline & \multicolumn{6}{|c|}{ Third cycle of production } \\
\hline Mass (g) & $\hat{\mathrm{Y}}=165.3+0.181571 \mathrm{x}^{* *}$ & 94 & 191.4 & $\hat{Y}=157.38+0.638 x-0.00259 x^{2 \star \star}$ & 86 & 195.7 \\
\hline Transverse diameter (mm) & $\hat{Y}=58.76+0.0691 x^{\star *}$ & 85 & 68.7 & $\hat{Y}=71,7115+0.202 x-0.0011 x^{2 \star *}$ & 98 & 78.5 \\
\hline Longitudinal diameter (mm) & $\hat{Y}=62.72+0.1078 x^{* *}$ & 96 & 78.2 & $\hat{Y}=69.6778+0.282 x-0.0014 x^{2 \star *}$ & 99 & 84.1 \\
\hline Soluble solids ( ${ }^{\circ} \mathrm{Brix}$ ) & $\hat{Y}=16.34+0.00959 x^{*}$ & 88 & 17.7 & $\hat{Y}=19.77+0.0393 x-0.00017 x^{2 * *}$ & 99 & 22.1 \\
\hline Titratable acidity (TA) (\%) & $\hat{Y}=0.51^{\mathrm{ns}}$ & - & 0.5 & $\hat{\mathrm{Y}}=0.24^{\mathrm{ns}}$ & - & 0.24 \\
\hline Total Sugars & $\hat{Y}=5.407+0.00698 x^{* *}$ & 94 & 6.4 & $\hat{Y}=6.42+0.00742 x^{* *}$ & 91 & 7.5 \\
\hline SS/TA Ratio & $=34.41^{\mathrm{ns}}$ & - & 34.4 & $\hat{\mathrm{Y}}=88.28^{\mathrm{ns}}$ & - & 88.3 \\
\hline Productivity (t ha-1) & $\hat{Y}=5.6545+0.01536 x^{* *}$ & 84 & 8.7 & $\hat{Y}=6.3470+0.00754 x^{* *}$ & 97 & 7.9 \\
\hline \multicolumn{7}{|c|}{ Fourth cycle of production } \\
\hline Mass $(\mathrm{g})$ & $\hat{Y}=136.623+0.4637 x^{\star *}$ & 92 & 203.4 & $\hat{Y}=137.67+1.119 x-0.00476 x^{2 \star *}$ & 97 & 200.8 \\
\hline Transverse diameter (mm) & $\hat{Y}=60.71+0.09278 x^{* *}$ & 79 & 74.1 & $\hat{Y}=52.985+0.364 x-0,0013 x^{2 \star *}$ & 92 & 78.5 \\
\hline Longitudinal diameter (mm) & $\hat{Y}=61.96+0.045194 x^{* *}$ & 81 & 68.5 & $\hat{Y}=54.085+0.3043 x-0.0012 x^{* *}$ & 91 & 78.5 \\
\hline Soluble solids (ํㅜix) & $\hat{Y}=17,02^{\text {ns }}$ & - & 17.0 & $\hat{Y}=19.26^{\text {ns }}$ & - & 19.3 \\
\hline Titratable acidity (TA) (\%) & $\hat{Y}=0.237-0.000286 x$ & 75 & 0.19 & $\hat{\mathrm{Y}}=0.17^{\mathrm{ns}}$ & - & 0.17 \\
\hline Total Sugars & $\hat{Y}=7.163+0.03348 x-0.000136 x^{2 * *}$ & 96 & 9.2 & $\hat{Y}=9.141+0.0401 x-0.00016 x^{2 * *}$ & 90 & 11.6 \\
\hline SS/TA Ratio & $\hat{\mathrm{Y}}=81.77^{\mathrm{ns}}$ & - & 81.8 & $\hat{Y}=113.23^{\text {ns }}$ & - & 113.2 \\
\hline Productivity (t ha-1) & $\hat{Y}=1.2151+0.079 x-0,00025 x^{2 \star \star}$ & 95 & 7.5 & $\hat{Y}=2.1105+0.02913 x^{* *}$ & 81 & 7.9 \\
\hline
\end{tabular}

Table 3: Regression equations and determination coefficient $\left(R^{2}\right)$ for protein, lipid, fiber, ash, carbohydrate, moisture, dry matter $(g$ $100 \mathrm{~g}^{-1}$ ) and energy value (kcal), as a function of the doses of $\mathrm{K}_{2} \mathrm{O}$ in pitayas of the Hylocereus undatus and Hylocereus polyrhizus species, in the second and third productive cycles

\begin{tabular}{|c|c|c|c|c|c|c|}
\hline \multirow[t]{3}{*}{ Variables } & Equation & $\mathbf{R}^{2}$ & $\begin{array}{l}\text { Maximum } \\
\text { value }\end{array}$ & Equation & $\mathbf{R}^{2}$ & $\begin{array}{c}\text { Maximum } \\
\text { value }\end{array}$ \\
\hline & \multicolumn{3}{|l|}{ H. undatus } & \multicolumn{3}{|l|}{ H. polyrhizus } \\
\hline & \multicolumn{4}{|c|}{ Third cycle of production } & & \\
\hline Proteins (\%) & $\hat{\mathrm{Y}}=1.2137^{\mathrm{ns}}$ & - & 1.2 & $\hat{\mathrm{Y}}=0.864^{\mathrm{ns}}$ & - & 0.86 \\
\hline Lipids (\%) & $\hat{Y}=1.1356^{\text {ns }}$ & - & 1.1 & $\hat{\mathrm{Y}}=1.11^{\mathrm{ns}}$ & - & 1.1 \\
\hline Fibers (\%) & $\hat{Y}=2.263+0.00714 x^{* *}$ & 92 & 3.3 & $\hat{\mathrm{Y}}=1.541+0.00493 \mathrm{x}^{* *}$ & 96 & 2.2 \\
\hline Ashes (\%) & $\hat{Y}=0.5+0,001293 x^{* *}$ & 94 & 0.68 & $\hat{\mathrm{Y}}=0.4905+0,000766 \mathrm{x}^{* *}$ & 91 & 0.6 \\
\hline Carbohydrates & $\hat{Y}=10.403+0.00914 x^{* *}$ & 87 & 11.7 & $\hat{Y}=12.3055+0.008023 x^{* *}$ & 92 & 13.5 \\
\hline Energy value (kcal) & $\hat{\mathrm{Y}}=60.17^{\mathrm{ns}}$ & - & 60.2 & $\hat{Y}=57.3867+0.2495 x-0.001 x^{2 * *}$ & 99 & 72.6 \\
\hline Moisture & $\hat{Y}=86.509-0.00667 x^{* *}$ & 75 & 85.5 & $\hat{Y}=85.621-0.01511 x^{\star \star}$ & 95 & 83.4 \\
\hline Dry matter & $\hat{Y}=13.441+0.00697 x^{* *}$ & 95 & 14.4 & $\hat{\mathrm{Y}}=13.269+0.01561 \mathrm{x}^{* *}$ & 94 & 15.5 \\
\hline \multicolumn{7}{|c|}{ Fourth cycle of production } \\
\hline Proteins (\%) & $\hat{Y}=1.0512^{\text {ns }}$ & - & 1.05 & $\hat{\mathrm{Y}}=0.71^{\mathrm{ns}}$ & - & 0,71 \\
\hline Lipids (\%) & $\hat{Y}=1.3287^{\text {ns }}$ & - & 1.3 & $\hat{\mathrm{Y}}=1.547^{\mathrm{ns}}$ & - & 1.55 \\
\hline Fibers (\%) & $\hat{Y}=3.0185+0.00389 x^{* *}$ & 83 & 3.6 & $\hat{\mathrm{Y}}=2.263+0.00361 \mathrm{x}^{*}$ & 85 & 2.78 \\
\hline Ashes (\%) & $\hat{Y}=0.352+0.00141 x^{\star *}$ & 84 & 0.55 & $\hat{\mathrm{Y}}=0.3365+0.001004 \mathrm{x}^{* *}$ & 90 & 0.48 \\
\hline Carbohydrates & $\hat{Y}=10.061+0.07112 x-0.00028 x^{2 * *}$ & 94 & 14.5 & $\hat{Y}=8.16664+0.09494 x-0.00035 x^{2 * *}$ & 93 & 14.5 \\
\hline energy value (kcal) & $\hat{\mathrm{Y}}=60.706+0.0668 \mathrm{x}^{* *}$ & 94 & 70.3 & $\hat{Y}=53,4465+0,3241 x-0,0013 x^{2 \star *}$ & 94 & 73.2 \\
\hline Moisture & $\hat{Y}=85.9665-0.023 x^{\star *}$ & 76 & 82.6 & $\hat{Y}=87.185-0,0226 x^{*}$ & 88 & 83.9 \\
\hline Dry matter & $\hat{Y}=12.985+0.0658 x-0.00025 x^{2 * *}$ & 95 & 17.3 & $\hat{Y}=11.1908+0.0917 x-0.00035 x^{2 * *}$ & 91 & 17.0 \\
\hline
\end{tabular}

${ }^{* *}=$ significant, at $1 \% ;{ }^{*}=$ significant, at $5 \%$; and $n s=$ not significant $\mathrm{p}<0.05$

from $10.4 \%$ and $11.7 \%$ to $11.7 \%$ and $14.5 \%$, when the plants received the dose of $144 \mathrm{~g}$ of $\mathrm{K}_{2} \mathrm{O}$, and in fruits of the H. polyrbizus species, from $12.3 \%$ and $8.1 \%$ to $13.4 \%$ and $14.4 \%$, in the third and fourth cycles, respectively (Table 3).

Pitayas harvested in plants with potassium fertilization showed higher energy value $(\mathrm{kcal})$. In fruits of the
$H$. undatus species, the energy value increased from $60 \mathrm{kcal}$ to $70 \mathrm{kcal}$ with the dose of $144 \mathrm{~g} \mathrm{~K}$ O. Similar results were observed in pitayas of the $H$. polyrbizus, values increased from $57 \mathrm{kcal}$ and $53 \mathrm{kcal}$ to $72 \mathrm{kcal}$ and $73 \mathrm{kcal}$, in the two harvests, respectively (Table 3 ).

As for moisture, a reduction of the content in the pitayas was observed with the availability of $\mathrm{K}_{2} \mathrm{O}$, in the two 
harvests evaluated (Table 3). The reduction varied from $86.5 \%$ to $85.5 \%$ and from $85.9 \%$ to $82.6 \%$, in the fruits of $H$. undatus and from $85.1 \%$ to $83.4 \%$ and from $87.2 \%$ and $83.9 \%$ in fruit of the $H$. pohyrbizus species.

The dry matter in the pitayas of the $H$. undatus and $H$. polyrizus species increased with potassium fertilization, in the two cycles evaluated. The dry matter content increased from $13.4 \%$ to $14.4 \%$ and from $12.9 \%$ to $17.2 \%$ in fruits of the species $H$. undatus and from $13.2 \%$ to $15.5 \%$ and from $11,1 \%$ to $17 \%$ in $H$. polyrbizus fruits.

\section{DISCUSSION}

The improvement of the variables related to the quality of pitayas is in agrees with what has been reported in relation to potassium fertilization in other fruit species, that is, that $\mathrm{K}$ is important in the production of good quality fruits. In other fruit species the action of $\mathrm{K}$ on fruit size increase is not exactly known, but it is admitted that it participates in the metabolic activities related to the synthesis and transport of carbohydrates and water to the fruits, resulting in an increase in fruit mass (Aular and Natale, 2013). For the pitaya, the increase in size was observed for three consecutive harvests, with the increase of orchard productivity, due to the increase of the $\mathrm{K}$ doses supplied to the plants, evidencing the action of $\mathrm{K}$ on the mass gain (Fernandes et al., 2018).

The improvement in the fruits composition with the availability of $\mathrm{K}_{2} \mathrm{O}$ occurs because this nutrient participates in metabolic processes, such as synthesis of proteins and sugars, being responsible for transporting sugars and carbohydrates to fruits. In addition, plants adequately supplied with $\mathrm{K}_{2} \mathrm{O}$ produce fruits with higher nutritional properties, such as, protein, oils and vitamins contents and flavor (Senapati and Santra, 2009; IPI, 2013). However, for the pitaya there were no studies correlating the fertilization of the plants with the composition of the fruits, being the results of this research pioneer.

The difference observed in the adjustment of the regression equations as a function of the doses of $\mathrm{K}_{2} \mathrm{O}$, mainly regarding the size variables, among the pitaya species in this work can be attributed to the vegetative vigor of the $H$. undatus species, which surpasses that of $H$. polyrhizus, with the emission of greater number and size of cladodes, which, possibly, increases the demand for nutrients.

The increase in the pitayas size is interesting for the marking, considering the classification of the fruits for the commercialization by the international standard. The pitayas produced with potassium fertilization are in class
$\mathrm{B}$ of the size table, while the fruits of the plants without fertilization are in class A (FAO, 2004), that is, they can reach higher prices in the market, considering that this characteristic associated to the other external variables that are responsible for the final quality.

Another important factor for the producer is that with the realizate of the adequate potassium fertilization, more fruits per plant were harvested (Table 2), that is, a larger quantity of fruits with a standard for commercialization. This is important because size is one of the variables that are directly linked to productivity. In the results of the third and fourth harvests evaluated, this can be observed, mainly in H. undatus species (Table 2), because it is a species that presents greater vegetative growth, in which the size varied in the two harvests evaluated, as a function of productivity achieved.

The results related to soluble solids content, total sugars and titratable acidity observed in the present study indicate that the potassium fertilization improved the quality variables of the pitayas. This is because the concentration of soluble solids has been associated with the amount of sugars in the fruit and, therefore, is a desirable characteristic, because the high the content in the fruit, the higher its acceptance by the consumers.

Fruits with soluble solids content higher than $12^{\circ}$ Brix or $13^{\circ}$ Brix present better acceptance for consumption (Wanitchang et al., 2010). Fruits with higher sugar contents are more accepted because the soluble sugars are responsible for the sweetness and flavor of fruits, which constitutes the majority of soluble solids in the form of glucose, fructose and sucrose (Cordeiro et al., 2015).

In addition to the influence of fertilization, it is possible to observe that there was variation in these variables as a function of the harvest season in the two productive cycles evaluated, which can be attributed to the rainfall incidence and the temperatures when the samples were harvested. Because in the place of cultivation the period of production of the pitaya species coincides with the rainy season. Thus, depending on the volume of rainfall in the days preceding the harvest, dilution of soluble sugars occurs in the fruits, directly reflecting in these variables. During the third harvest there was a higher concentration of rain during the period of formation, growth and harvest of the fruits, and different temperature variations compared to fourth cycle productive.

The sugar content increases during the development of pitayas, reaching from 7\% to $9 \%$ (Nerd et al., 2002; Osorio et al., 2013). In the present work, the content varied from $6.4 \%$ to $11.6 \%$ in the pitayas harvested in plants fertilized with $\mathrm{K}_{2} \mathrm{O}$. 
The observed improvement in the quality of pitayas with potassium fertilization can be related to the enzymatic activation that is essential for the production and redistribution of sugars for fruits (IPI, 2013).

For titratable acidity, the results observed in relation to the low acid percentages, is a characteristic of pitayas, which makes them flavored smooth. The results reported for the pitayas vary from $0.07 \%$ to $0.51 \%$ (Moreira et al., 2011; Lima et al., 2013; Cordeiro et al., 2015; Fernandes et al., 2018). The variation in acidity may be related to the maturation stage at the time of harvest (Ortiz and Takahashi, 2015) and to the time and storage conditions, which can reduce the acidity rapidly as a function of the metabolic and physiological processes (Brunini and Cardoso, 2011; Duarte et al., 2017) that use organic acids as a substrate for respiration. In addition, the climatic conditions can influence this variable, since the occurrence of rains can cause the dilution of organic acids in the fruits.

The change SS / TA ratio in the pitayas is most often caused by the drastic reduction of acidity, so that the high SS / TA ratio does not always indicate satisfactory contents of soluble solids (Osuna Enciso et al., 2011). Some authors consider the ideal value of the SS / TA ratio in pitayas of approximately 40 , which occurs in mature fruits with $0.4 \%$ acidity (To et al., 2002).

The increase in soluble solids contents and the reduction in acidity contribute to increase SS / TA ratio in fruits and consumer acceptance. Considering this variable, it is worth mentioning the pitayas of the H. polyrbizus species, which present a high relation, more than double the ideal value, between 88.1 and 123 , indicating that the fruits of this species present a more attractive flavor compared to H. undatus.

For protein concentrations, the observed results show that the production of proteins in the plant depends of the $\mathrm{N}$ that is transported from the roots to the aerial part, and the $\mathrm{K}$ assists in this transport, since it determines the balance of salts and water in the plant. For the pitaya's species evaluated, the availability of $\mathrm{N}$ can had been lower than that of $\mathrm{K}$. Thus, probably because of this reason the increase of the potassium doses did not interfere in the contents of protein.

In relation to lipids, the contents in the pitayas can be high if the methodology used to extract oil from the seeds, since they have high oil content, reaching yield of $18.33 \%$ to $28.37 \%$. (Lim et al., 2010). Thus, the low lipids contents evaluated in this study may be related to the methodology used, since the analysis was done in the pulp containing the intact seeds.

\section{CONCLUSIONS}

Pitaya species fertilized with potassium produce larger fruits and better flavor, improving the final quality. The centesimal composition of pitayas is altered with the management of orchard fertilization.

The Hylocereus undatus and Hylocereus polyrbizus species with the availability of potassium produce fruits most rich in fibers, minerals, carbohydrates and energetic value, and with lower humidity, allowing the preservation for longer if properly stored.

\section{ACKNOWLEDGMENT}

This study was financed in part by the Coordination for the Improvement of Higher Education Personnel (CAPES) - Brazil - Finance Code 001. The Federal University of the Jequitinhonha and Mucuri Valley (UFVJM) provided the infrastructure needed to conduct this study.

\section{Authors' contributions}

Josimara Mendes Rabelo, Cíntia Gonçalves Sena and Letícia Alves Carvalho designed and performed experiments, in addition to analysed data. Maria do Céu Monteiro Cruz, Lílian de Araújo Pantoja and Alexandre Soares dos Santos supervised the research. Amanda Gonçalves Guimarães wrote the paper. All authors read and approved the final manuscript.

\section{REFERENCES}

Abreu, W. C., C. O. Lopes, K. M. Pinto, L. M. Oliveira, G. B. M. Carvalho and M. F. P. Barcelos. 2012 Características físico-químicas e atividade antioxidante total de pitaias vermelha e branca. Inst. Adolfo Lutz. 71: 656-661.

Aular, J. and W. Natale. 2013. Nutrição mineral e qualidade do fruto de algumas frutíferas tropicais: goiabeira, mangueira, bananeira e mamoeiro. Rev. Bras. Frutic. 35: 1214-1231.

Brazil. 2003. Agência Nacional de Vigilância Sanitária: Resolução RDC n. 360, de 23 de dezembro de 2003. Regulamento Técnico sobre Rotulagem Nutricional de Alimentos Embalados.

Brunini, M. A. and S. S. Cardoso. 2011. Qualidade de pitayas de polpa branca armazenadas em diferentes temperaturas. Rev. Caatinga. 24: 78-84.

FAO. 2004. Codex Stan. 237-2003, Codex Standard for Pitahayas. Food and Agriculture Organization, United Nations.

Cordeiro, M. H. M., J. M. Silva, G. P. Mizobutsi, E. H. Mizobutsi and W. F. Mota. 2015. Caracterização física, química e nutricional da pitaya-rosa de polpa vermelha. Rev. Bras. Frutic. 37: 20-26.

Duarte, M. H., E. R. Queiroz, D. A. Rocha, A. C. Costa and C. M. P. Abreu. 2017. Qualidade de pitaya (Hylocereus undatus) submetida à adubação orgânica e armazenada sob refrigeração. Braz. J. Food Technol. 20: e2015115.

Fernandes, D. R., R. A. Moreira, M. C. M. Cruz, J. M. Rabelo and J. Oliveira. 2018. Improvement of production and fruit quality of 
pitayas with potassium fertilization. Acta Sci. Agron. 40: e35290.

Freitas, S. T. and E. J. Mitcham. 2013. Quality of pitaya fruit (Hylocereus undatus) as influenced by storage temperature and packaging. Sci. Agric. 70: 257-262.

IAL. 2008. Métodos Físico-químicos Para Análise de Alimentos. Instituto Adolfo Lutz, São Paulo, Brazil.

IPI. 2013. Potássio, o Elemento da Qualidade na Produção Agrícola. International Potash Institute, Switzerland. Available from: https://www.ipipotash.org/udocs/419-kquality_booklet_ portuegese_web.pdf. [Last accessed on 2017 Dec 17].

Jerônimo, M. C., J. V. C. Orsine, K. K. Borges and M. R. C. Novaes. 2015. Chemical and physical-chemical properties, antioxidant activity and fatty acids profile of red pitaya [Hylocereus undatus (Haw.) Britton and Rose] grown In Brazil. J. Drug Metab. Toxic. 6: 1-6.

Lim, H. K., C. P. Tan, R. Karim, A. A. Ariffin and J. Bakar. 2010. Chemical composition and DSC thermal properties of two species of Hylocereus cacti seed oil: Hylocereus undatus and Hylocereus polyrhizus. Food Chem. 119: 1326-1331.

Lima, C. A., F. G. Faleiro, N. T. V. Junqueira, K. O. Cohen and T. G. Guimarães. 2013. Características físico-químicas, polifenóis e flavonoides amarelos em frutos de espécies de pitaias comerciais e nativas do Cerrado. Rev. Bras. Frutic. 35: 565-570.

Mccready, R. M., J. Guggolz, V. Silviera and H. S. Owens. 1950. Determination of starchandamylose in vegetables. Anal. Chem. 22: 1156-1158.

Mizrahi, Y. 2014. Vine-cacti pitayas the new crops of the world. Rev. Bras. Frutic. 36: 124-138.

Nerd, A., N. Tel-Zur and Y. Mizrahi. 2002. Fruits of Vine and Columnar Cacti. In: P. S. Nobel (Ed.), Cacti: Biology and Uses. University of California Press, Los Angeles, USA, pp. 185-197.
Nurul, S. R. and R. Asmah. 2014. Variability in nutritional composition and phytochemical properties of red pitaya (Hylocereus polyrhizus) from Malaysia and Australia. Int. Food Res. J. 21: 1689-1697.

Ortiz, T. A. and L. S. A. Takahashi. 2015. Physical and chemical characteristics of pitaya fruits at physiological maturity. Genet. Mol. Res. 14: 14422-14439.

Osorio, S., F. Scossa and A. Fernie. 2013. Molecular regulation of fruit ripening. Front. Plant Sci. 4: 198.

Osuna, E. T., Z. M. E. Ibarra, R. M. D. Muy and T. J. B. Valdez. 2011. Calidad postcosecha de frutos de pitahaya (Hylocereus undatus Haw.) cosechados en tresestados de madurez. Rev. Fitotec. Mex. 34: 63-72.

Santos, M. R. P., J. C. Castro, L. P. Mardigan, R. Watanabe and E. Clemente. 2016. Características físico-químicas, compostos bioativos, atividade antioxidante e enzimática de frutos da pitaia (Hylocereus undatus). Rev. Bras. Tecnol. Agroindustr. 10: 20812095.

Sato, S. T. A., S. C. A. Ribeiro, M. K. Sato and J. N. S. Souza. 2014. Caracterização física e físico-química de pitayas vermelhas (Hylocereus costaricensis). J. Bioen. Food Sci. 1: 6-56.

Senapati, H. K. and G. H. Santra. 2009. Potassium Management in Vegetables, Spices and Fruit Crops. Available from: https://www. ipipotash.org/udocs/Potassium_Management_in_Vegetables Spices_and_Fruit_Crops.pdf. [Last accessed on 2018 Mar 28].

To, L. V., N. Ngu, N. D. Duc and H. T. T. Huong. 2002. Dragon fruit quality and storage life: Effect of harvest time, use of plant growth regulators and modified atmosphere packaging. Acta Hortic. 575: 611-621.

Wanitchang, J., A. Terdwongworakul, P. Wanitchang and S. Noypitak. 2010. Maturity sorting index of dragon fruit: Hylocereus polyrhizus. J. Food Eng. 100: 409-416. 